\title{
X-RAY RADIOGRAPHY OF AISI 4340-2205 STEELS WELDED BY FRICTION WELDING
}

\author{
RENTGENSKI PREGLED JEKEL AISI 4340-2205, VARJENIH \\ $S$ TRENJEM
}

\author{
Ugur Caligulu1, Mahmut Yalcinoz ${ }^{2}$, Mustafa Turkmen ${ }^{3}$, Serdar Mercan $^{4}$ \\ 1Firat University, Faculty of Technology, Dept. of Met. and Materials Eng., Elazig, Turkey \\ ${ }^{2}$ Firat University, Faculty of Technical Education, Dept. of Metallurgy Education, Elazig, Turkey \\ ${ }^{3}$ Kocaeli University, Hereke Vocational School, 41800 Kocaeli, Turkey \\ ${ }^{4}$ Cumhuriyet University, Faculty of Technology, Dept. of Mechatronic Eng., Sivas, Turkey \\ ucaligulu@firat.edu.tr
}

Prejem rokopisa - received: 2014-08-25; sprejem za objavo - accepted for publication: 2015-03-04

doi:10.17222/mit.2014.211

\begin{abstract}
In this study, X-ray radiographic tests of friction-welded AISI 4340-AISI 2205 steels were investigated. AISI 4340 tempered steel and AISI 2205 duplex stainless steel, each of $12 \mathrm{~mm}$ diameter, were used to fabricate the joints. The friction-welding tests were carried out using a direct-drive-type friction-welding machine for different parameters. After this process, the radiographic tests of the welded joints were examined by X-ray diffraction. The experimental results indicated that the AISI 4340 tempered steel could be joined to the AISI 2205 duplex stainless steel using the friction-welding technique and for achieving a weld with sufficient strength. The result of the radiographic tests indicated that by increasing the rotation speed, the friction pressure and the forging pressure, the amount of flash increased for all the specimens. In contrast, when increasing the friction time the amount of flash decreased. The best properties for steels AISI 4340-2205 were observed for the specimens welded at a rotation speed of $2200 \mathrm{~min}^{-1}$, a friction pressure of $40 \mathrm{MPa}$, a forging pressure of $80 \mathrm{MPa}$, a friction time of $6 \mathrm{~s}$ and a forging time of $3 \mathrm{~s}$. Keywords: AISI 4340, AISI 2205, friction welding, radiographic test
\end{abstract}

V tej študiji so bili rentgensko pregledani spoji jekel AISI 4340-AISI 2205, zvarjeni s trenjem. Spoji so bili izdelani s popuščenim AISI 4340 jeklom in AISI 2205 dupleks nerjavnim jeklom, vsako premera $12 \mathrm{~mm}$. Preizkus varjenja s trenjem je bil izvršen $\mathrm{z}$ uporabo neposredno gnanega stroja za varjenje s trenjem, pri različnih parametrih. Po tem postopku so bili zvarjeni spoji pregledani z rentgenom. Rezultati preizkusov so pokazali, da je z varjenjem s trenjem mogoče spojiti AISI 4340 popuščeno jeklo in AISI 2205 dupleks nerjavno jeklo in da je mogoče dobiti zvar z zadostno trdnostjo. Rezultati rentgenskih preiskav so pokazali, da pri naraščajoči hitrosti vrtenja, tornega tlaka in tlaka pri kovanju delež zmehčanega roba narašča pri vseh vzorcih. Nasprotno pa se pri podaljšanju časa trenja zmanjša količina zmehčanega roba. Najboljše lastnosti pri jeklih AISI $4340-2205$ so bile opažene pri vzorcih, varjenih z rotacijo $2200 \mathrm{~min}^{-1}$, tornim tlakom $40 \mathrm{MPa}$, kovaškim tlakom $80 \mathrm{MPa}$, časom trenja $6 \mathrm{~s}$ in časom kovanja $3 \mathrm{~s}$.

Ključne besede: AISI 4340, AISI 2205, varjenje s trenjem, rentgensko testiranje

\section{INTRODUCTION}

Duplex stainless steel (DSS) is well known for its excellent strength and corrosion resistance. However, joining DSS plates by fusion welding causes a significant reduction in the mechanical properties, because of microstructure changes during weld solidification. It is essential to maintain the characteristics of the weld zone to use DSS in servicing highly critical environments, such as ocean-mining machinery, oil and gas pipe lines, desalination plants and chemical tankers of ships, etc. DSS has ferrite $(\alpha)$ and austenite $(\gamma)$ in approximately equal proportions, which possess body centered cubic (BCC) and face centered cubic structure (FCC), respectively. ${ }^{1}$ During the controlled alloying process of the DSS, under equilibrium conditions, ferrite-promoting elements (Cr, Mo, Mn, W, Nb, Si, Ti and V) will concentrate by diffusing in the ferrite. At the same time, austenite-promoting elements $(\mathrm{Ni}, \mathrm{C}, \mathrm{N}, \mathrm{Co}$ and $\mathrm{Cu}$ ) will concentrate by diffusing in the austenite phases. This gives the formation of a dual-phase microstructure. ${ }^{2,3}$ But the welding of DSS forces the microstructure to remain in an excessive ferritic nature, because of the higher amounts of ferrite promoting elements in its chemical composition, and also due to a faster cooling rate. Austenite usually nucleates in the temperature range $1200-900{ }^{\circ} \mathrm{C}$. During cooling, the weld zone remains in this temperature range for a very short period of time, i.e., from $4 \mathrm{~s}$ to $15 \mathrm{~s}$. Thus, the arc energy and filler metal composition play a major role in the microstructural stability after welding. ${ }^{4}$

Tempered types of steel are machinery manufactured steels with and without alloy, whose chemical compositions, especially in terms of carbon content, are suitable for hardening and which show high toughness under a specific tensile strength at the end of the tempering process. Tempered types of steel, due to their superior mechanical properties, acquired at the end of the tempering process, are used in a wide range of areas, including the manufacture of parts such as various machine and engine parts, forging parts, various screws, nuts and stud 
bolts, crank shafts, shafts, control and drive components, piston rods, various shafts, gears. For this reason, tempered steels are the type of steel used and produced at the highest rate after unalloyed steels and construction steels. These steels constitute the most important part of the machinery-manufacturing steels. Generally, such steels are used for the production of fitting, axle shaft, the shaft and the gear. ${ }^{5-9}$

Friction welding is a solid-state joining process that can be used to join a number of different metals. The process involves making welds in which one component is moved relative to, and in pressure contact with, the mating component to produce heat at the faying surfaces. Softened material begins to extrude in response to the applied pressure, creating an annular upset. Heat is conducted away from the interfacial area for forging to take place. The weld is completed by the application of a forge force during or after the cessation of the relative motion. The joint undergoes hot working to form a homogenous, full surface, high-integrity weld. Friction welding is the only viable method in this field to overcome the difficulties encountered in the joining of dissimilar materials with a wide variety of physical characteristics. The advantages of this process are, among others, no melting, high reproducibility, short production time and a low energy input. ${ }^{10-19}$

Welding technology is commonly used in many areas. Because it is aimed to provide high and constant quality in manufacturing sector and in products, the importance of non-destructive is the testing methods in quality-control strategies. Accordingly, the non-destructive testing of welded joints has become a part of the total quality system. ${ }^{20,21}$ Being one of the most important parts of quality control, non-destructive material testing method is the complementary part of the manufacturing. The non-destructive method is the common name for testing methods through which the static and dynamic information about the materials are obtained by testing the materials without damaging them. Thanks to the non-destructive testing method, defects such as cracks occurred during manufacturing or after used for a while, space in internal structure, edge reduction, etc., are detected (Table 1).

The methods applied in non-destructive testing are visual testing, liquid-penetrant testing, eddy-current testing, magnetic particle inspection, ultrasonic inspection and radiographic inspection. ${ }^{22}$

High-energy electromagnetic waves may penetrate into many materials. The radiation penetrating a specific material may affect the radiation-sensitive films that are put on the other side of the material. After the development of the films, the image of the inside of the material is seen. This image occurs because of the spaces in the material or thickness/density changes. This method is called radiographic testing, which is one of the oldest methods of nondestructive testing and has been in use for approximately five decades. Among the advantages of this method, compared to other methods, such as ultrasound tests, is the formation of an internal 'photograph' of the material, which no other method is able to achieve. Various radiation sources may be used in radiographic testing. The radiographic testing of weld bead or casting pieces using X-rays or gamma source is one of the most important uses for this inspection method. The energy gap of the X-ray used in industrial radiography is generally between $50 \mathrm{kV}$ and $350 \mathrm{kV}$. The beam energy varies according to the type and thickness of the material. In order to get precise results from the testing, it has to be done in accordance with the standards. These standards are determined by considering the type of the material and/or the type of product. There are also application standards together with the standards according to which the acceptance levels are determined. The testing is done by determining the standards suitable for the features of the product. Radiographic testing is generally applied according to the EN 1435 or EN 12517 standards. ${ }^{23-25}$ The radiography method is applied to ferromagnetic, non-ferromagnetic metals and other all materials. Because X-ray provides the opportunity to analyze the microstructure of the materials without making any damage, it is widely used in non-destructive testing. Via $\mathrm{X}$-ray or gamma ray, thickness changes, structural

Table 1: Non-destructive testing experiments in industrial areas ${ }^{37}$ Tabela 1: Neporušne preiskave na področju industrijskih preiskav ${ }^{37}$

\begin{tabular}{|l|l|l|}
\hline Practice Area & \multicolumn{1}{|c|}{ Function } \\
\hline $\begin{array}{l}\text { Research and } \\
\text { Development }\end{array}$ & $\begin{array}{l}\text { Structural evaluation of materials, Comparison of } \\
\text { production and assembly methods and evaluation } \\
\text { findings. }\end{array}$ & $\begin{array}{l}\text { Examination of fatigue and microstructure of metals } \\
\text { and the detection of cracks in the welding seam. }\end{array}$ \\
\hline $\begin{array}{l}\text { Production } \\
\text { Methol }\end{array}$ & $\begin{array}{l}\text { Determination of the variable production method and } \\
\text { to control. }\end{array}$ & $\begin{array}{l}\text { Radiographic and ultrasonic thickness measuring } \\
\text { method and determination of the manufacturing } \\
\text { parameters. }\end{array}$ \\
\hline $\begin{array}{l}\text { Quality } \\
\text { Control }\end{array}$ & $\begin{array}{l}\text { Defective parts and the detection of abnormalities, } \\
\text { Manufacturing assembly defects, place and method of } \\
\text { evaluation. }\end{array}$ & $\begin{array}{l}\text { Poor adhesion, cracking in welding, metal in the } \\
\text { non-uniform pores and the determination of material } \\
\text { defects. }\end{array}$ \\
\hline $\begin{array}{l}\text { During the } \\
\text { service } \\
\text { evaluation }\end{array}$ & $\begin{array}{l}\text { Wear and use during the early identification of } \\
\text { abnormalities. }\end{array}$ & $\begin{array}{l}\text { Corrosion in pipes and location of warehouses and } \\
\text { detection, Variety of early-warning systems in } \\
\text { vehicles. }\end{array}$ \\
\hline
\end{tabular}


Table 2: Chemical compositions of test materials

Tabela 2: Kemijska sestava preizkusnih materialov

\begin{tabular}{|c|c|c|c|c|c|c|c|c|c|c|}
\hline \multirow{2}{*}{ Materials } & \multicolumn{10}{|c|}{ Alloy Elements $(w / \%)$} \\
\hline & $\mathrm{C}$ & $\mathrm{Mn}$ & $\mathrm{Si}$ & $\mathrm{P}$ & $S$ & $\mathrm{Cr}$ & Mo & $\mathrm{Ni}$ & $\mathrm{N}$ & $\mathrm{Cu}$ \\
\hline AISI 4340 & 0.4 & 0.8 & 0.3 & 0.035 & 0.040 & 0.9 & 0.3 & 2.00 & - & - \\
\hline AISI 2205 & 0.018 & 1.686 & 0.309 & 0.026 & 0.003 & 22.333 & 3.379 & 4.932 & 0.191 & 0.097 \\
\hline
\end{tabular}

Table 3: Mechanical properties of copper and low carbon steel

Tabela 3: Mehanske lastnosti bakra in malo ogljičnega jekla

\begin{tabular}{|c|c|c|c|c|}
\hline Materials & $\begin{array}{c}\text { Tensile Strength } \\
(\mathrm{MPa})\end{array}$ & $\begin{array}{c}\text { Yield Strength 0.2 \% } \\
(\mathrm{MPa})\end{array}$ & $\begin{array}{c}\text { Elongation } \\
(\%)\end{array}$ & $\begin{array}{c}\text { Microhardness } \\
(\mathrm{HV})\end{array}$ \\
\hline AISI 4340 & 659 & 400 & 20.98 & 201 \\
\hline AISI 2205 & 956 & 620 & 20 & 328 \\
\hline
\end{tabular}

changes, inner defects, montage details can be determined. ${ }^{26-30}$

The conventional method of inspection requires that the radiographic images are first-rate and are consequently controlled by international standards. However, radiographic inspection by inspectors is done subjectively and requires great experience, keenness of vision and knowledge of the techniques employed, and yet even when done adequately, interpretation errors occur whether it be the non-detection of a defect present or the incorrect classification of a detected defect. ${ }^{25,31-33}$ The advantages of the radiography method may be seen as follows, the result is shown with an image, permanent records that may be seen outside of the test area can be obtained, the sensitivity is shown on every film and it may be applied to any kind of material. As for the disadvantages, they may be sorted as follows, it is not suitable for thick pieces, may be harmful to health, direct calorie is needed for two-dimensional faults, the film needs posing and showing, is not suitable for automation, surface defects, and it does not give information about the depth of the defect under the surface. The equipment that is used is rather expensive in comparison with other methods and at most it needs careful work concerning the radiation safety. ${ }^{34}$

In the present paper, X-ray radiographic testing of AISI 4340-2205 steels welded by friction welding were investigated.

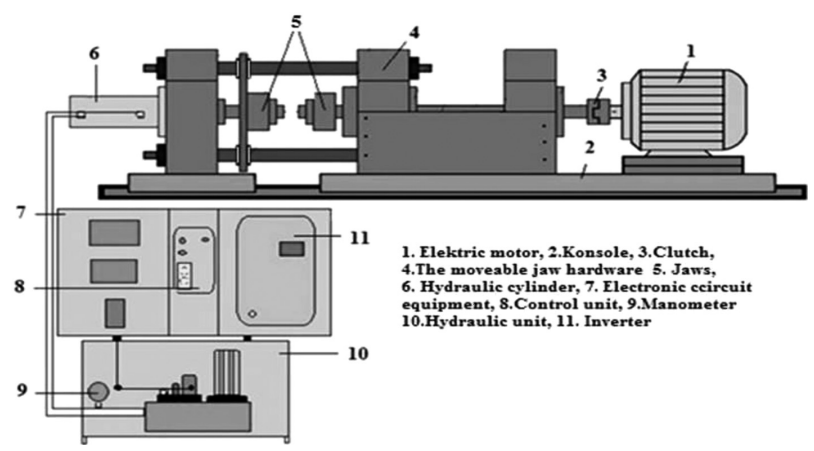

Figure 1: Experimental set-up ${ }^{17}$

Slika 1: Eksperimentalni sestav ${ }^{17}$

\section{MATERIALS AND METHODS}

AISI 4340 tempered steel and AISI 2205 duplex stainless steel of $12 \mathrm{~mm}$ diameter were used to fabricate the joints in this study. Table 2 illustrates the chemical compositions of the base metals. The friction-welding tests were carried out using a direct-drive-type frictionwelding machine. Table 3 has the mechanical properties and Table 4 has the physical properties of AISI 4340 and AISI 2205 steels. Table 5 illustrates the experimental conditions. The experimental set-up is shown in Figure 1. ${ }^{17}$

Table 4: Physical properties of copper and low carbon steel Tabela 4: Fizikalne lastnosti bakra in malo ogljičnega jekla

\begin{tabular}{|c|c|c|c|c|}
\hline Materials & $\begin{array}{c}\alpha \\
\left(10^{-6}\right)\end{array}$ & $\begin{array}{c}\lambda \\
\left(\mathrm{W} / \mathrm{m}^{\circ} \mathrm{C}\right)\end{array}$ & $\begin{array}{c}\Omega \\
(\mathrm{n} \Omega \mathrm{m})\end{array}$ & $\begin{array}{c}E \\
(\mathrm{GPa})\end{array}$ \\
\hline AISI 4340 & & & & \\
\hline AISI 2205 & 14.7 & 19 & 85 & 200 \\
\hline
\end{tabular}

$\alpha$ : Thermal Expansion Coefficient $\left(20-800{ }^{\circ} \mathrm{C}\right)$

$\lambda$ : Thermal Conductive $\left(20^{\circ} \mathrm{C}\right)$

$\Omega$ : Electrical Resistance $\left(20^{\circ} \mathrm{C}\right)$

$E$ : Elastic modulus $\left(20^{\circ} \mathrm{C}\right)$

After the friction-welding procedure the specimens were divided into sections transversely in order to investigate the microstructural variations from the centre to the outside of the weld. Transverse sections were prepared, and then grinding and polishing with $3-\mu \mathrm{m}$ diamond paste were made in order to conduct a metallographic examination of the joined materials. The specimens were etched in a chemical solution for AISI $43402 \% \mathrm{HNO}_{3}+98 \%$ alcohol and in a solution for AISI $220525 \% \mathrm{HNO}_{3}+75 \%$ pure water to conduct the microstructural examination $(7.5 \mathrm{~V}+30 \mathrm{~s})$ The microstructures of the joints were observed using light microscopy (LM), the energy-dispersive spectroscopy (EDS) and X-ray diffraction (XRD). Microhardness measurements were taken under a load of $50 \mathrm{~g}$. The tensile tests were conducted at room temperature with $10^{-2} \mathrm{~mm} \mathrm{~s}^{-1}$ cross-head rate.

In controlling the weld seam, as the thickness is 4 $\mathrm{mm}$, radiographic testing was chosen from among the 
non-destructive methods and an X-ray tube was chosen as the radiation source. The principle can be seen in Figure $2 .{ }^{35,36}$

Table 5: The process parameters used in the friction welding Tabela 5: Parametri procesa, uporabljeni pri varjenju s trenjem

\begin{tabular}{|c|c|c|c|c|c|c|}
\hline \multirow{2}{*}{$\begin{array}{c}\text { Sample } \\
\text { no }\end{array}$} & $\begin{array}{c}\text { Rotating } \\
\text { speed } \\
\left(\mathrm{min}^{-1}\right)\end{array}$ & $\begin{array}{c}\text { Friction } \\
\text { pressure } \\
(\mathrm{MPa})\end{array}$ & $\begin{array}{c}\text { Forging } \\
\text { pressure } \\
(\mathrm{MPa})\end{array}$ & $\begin{array}{c}\text { Friction } \\
\text { time } \\
(\mathrm{s})\end{array}$ & $\begin{array}{c}\text { Forging } \\
\text { time } \\
(\mathrm{s})\end{array}$ & $\begin{array}{c}\text { Axial } \\
\text { short- } \\
\text { ening } \\
(\mathrm{mm})\end{array}$ \\
\hline S1 & 2200 & 30 & 60 & 6 & 3 & 4.00 \\
\hline S2 & 2200 & 30 & 60 & 10 & 5 & 4.37 \\
\hline S3 & 2100 & 30 & 60 & 6 & 3 & 3.15 \\
\hline S4 & 2100 & 30 & 60 & 10 & 5 & 3.41 \\
\hline S5 & 2000 & 30 & 60 & 6 & 3 & 2.10 \\
\hline S6 & 2000 & 30 & 60 & 10 & 5 & 2.80 \\
\hline S7 & 2200 & 40 & 80 & 6 & 3 & 4.50 \\
\hline S8 & 2200 & 40 & 80 & 10 & 5 & 4.78 \\
\hline S9 & 2100 & 40 & 80 & 6 & 3 & 3.44 \\
\hline S10 & 2100 & 40 & 80 & 10 & 5 & 3.96 \\
\hline S11 & 2000 & 40 & 80 & 6 & 3 & 2.20 \\
\hline S12 & 2000 & 40 & 80 & 10 & 5 & 2.60 \\
\hline
\end{tabular}

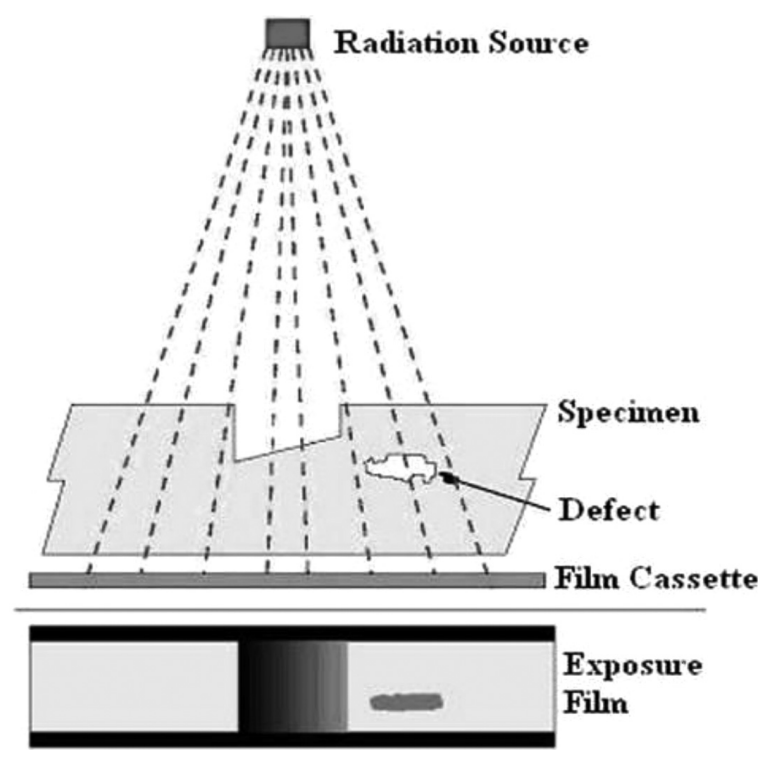

Figure 2: Working principle of radiographic test ${ }^{35,36}$ Slika 2: Princip delovanja rentgenskega preizkusa ${ }^{35,36}$

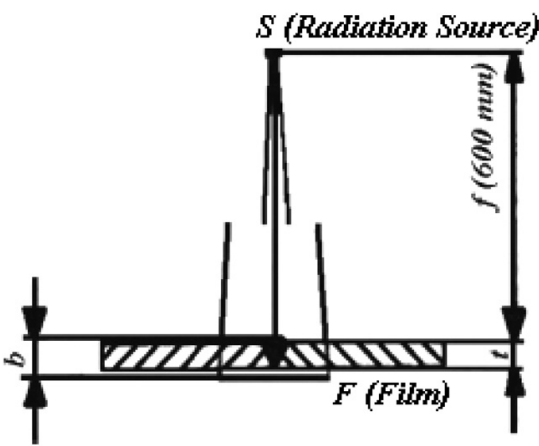

Figure 3: Test preparation for plane wall and one wall Slika 3: Priprava preizkusa za ravno steno

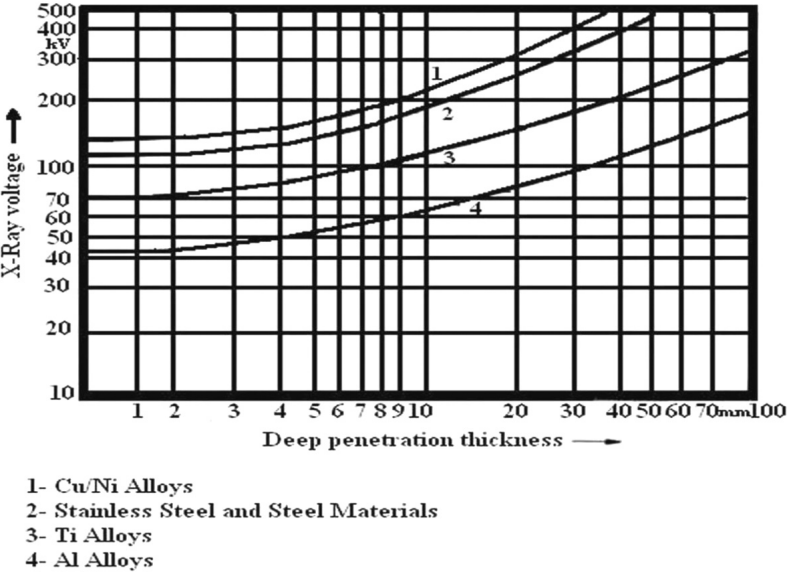

Figure 4: The deep-penetration thickness and material as a function up to $500 \mathrm{kV}$ for the X-ray device and to determine the voltage plot graphic

Slika 4: Debelina globine penetracije pri materialu v odvisnosti od napetosti do $500 \mathrm{kV}$ za rentgensko napravo in za določanje diagrama napetost debelina

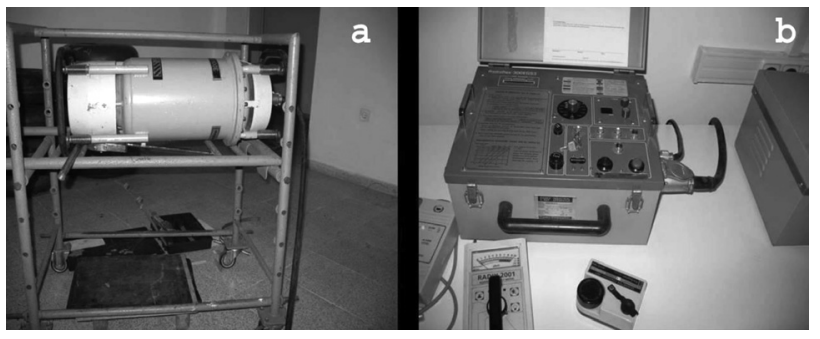

Figure 5: a) Rigaku mark Radioflex-300EGS3-type device and b) control panel

Slika 5: a) Naprava vrste Rigaku Radioflex-300EGS3 in b) kontrolna plošča

Tests TS 5127 and EN 1435 were applied, according to the standards, in class B and in a type that will cover the area affected by the weld and the heat (Figure 3 ).

The X-ray tension that was chosen according to the thickness of the material was $130 \mathrm{kV}$ to image (Figure 4).

The X-ray device, Rigaku Radioflex-300EGS3 type, having the capacity of $300 \mathrm{kV}$ was used (Figures $\mathbf{5 a}$ and 5b).

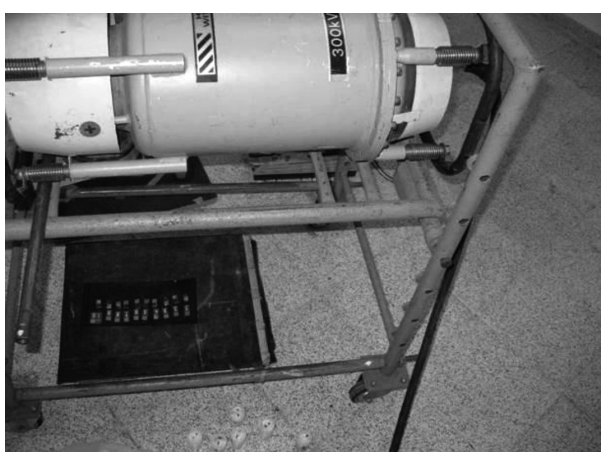

Figure 6: Film, penetremeter, stenciling pattern and beam setting Slika 6: Film, merilec globine penetracije, vzorec šablone, nastavitev snopa 
Table 6: Definition of weld defects and radiographic image $\mathrm{e}^{37,38}$

Tabela 6: Definicije napak zvarov in rentgenskih posnetkov ${ }^{37,38}$

\begin{tabular}{|c|c|c|}
\hline \multirow{2}{*}{$\begin{array}{l}\text { A: Gas gaps } \\
\text { Aa: Porosity } \\
\text { Ab: Gas bubbles }\end{array}$} & Description & $\begin{array}{l}\text { * Because the captured gas bubbles are formed. } \\
\text { * Gas channels or long gaps }\end{array}$ \\
\hline & $\begin{array}{l}\text { Radiographic } \\
\text { Image }\end{array}$ & $\begin{array}{l}\text { * Sharp black shadows around the circle. } \\
\text { * Sharp black depending on the round or the long shadows of the error change. }\end{array}$ \\
\hline \multirow{2}{*}{$\begin{array}{l}\text { B: Slag } \\
\text { Ba: Slag } \\
\text { Bb: Slag errors }\end{array}$} & Description & $\begin{array}{l}\text { * Slag or other foreign materials during the welding. } \\
\text { * Captured within gaps slag or foreign matter. }\end{array}$ \\
\hline & $\begin{array}{l}\text { Radiographic } \\
\text { Image }\end{array}$ & $\begin{array}{l}\text { * Dark shadows or random shapes. } \\
* \text { Continuous dark lines parallel to the seam edge welding. }\end{array}$ \\
\hline \multirow[t]{2}{*}{$\begin{array}{l}\text { C. Insufficient } \\
\text { Welding }\end{array}$} & Description & $\begin{array}{l}\text { Between the main material source material during welding seam merger due to lack } \\
\text { of two-dimensional error. }\end{array}$ \\
\hline & $\begin{array}{l}\text { Radiographic } \\
\text { Image }\end{array}$ & Sharp-edged thin dark line. \\
\hline \multirow[t]{2}{*}{$\begin{array}{l}\text { D. Insufficient Deep } \\
\text { Penetration }\end{array}$} & Description & $\begin{array}{l}\text { Merger at the root welding of the lack of sewing filled fully with the welding or } \\
\text { root. }\end{array}$ \\
\hline & $\begin{array}{l}\text { Radiographic } \\
\text { Image }\end{array}$ & The middle of the dark seam continuous or discrete line welding. \\
\hline \multirow{2}{*}{$\begin{array}{l}\text { E. Cracks } \\
\text { Ea: Vertical Cracks } \\
\text { Eb: Horizontal } \\
\text { Cracks }\end{array}$} & Description & Local tensile strength of metal exceeded. \\
\hline & $\begin{array}{l}\text { Radiographic } \\
\text { Image }\end{array}$ & Flat thin dark line. \\
\hline \multirow[t]{2}{*}{ F. Swelter Channel } & Description & Welding material on the surface along the seam formed channel or groove. \\
\hline & $\begin{array}{l}\text { Radiographic } \\
\text { Image }\end{array}$ & Weldings are spread wide and dark line along the seam. \\
\hline
\end{tabular}

C4 type, $100 \times 240 \mathrm{~mm}^{2}$ Kodak film was used. Front and back lead screens with a thickness of $0.125 \mathrm{~mm}$ were used. The weld seam applied to the material with the thickness of $4 \mathrm{~mm}$ was filmed by sending the beam to the pose diagram for $48 \mathrm{~s}$. The distance between the X-ray device and film was $600 \mathrm{~mm}$. The placement of the film is shown in Figure $6 .^{37,38}$

\section{RESULTS AND DISCUSSION}

The flash obtained was symmetric, which indicated plastic deformation on both the rotating and upsetting (reciprocating) side. The integrity of the joints was evaluated for the friction-welded joints. The friction-processed joints were sectioned perpendicular to the bond line and observed through an optical microscope. It is clear that there were no cracks and voids in the weld

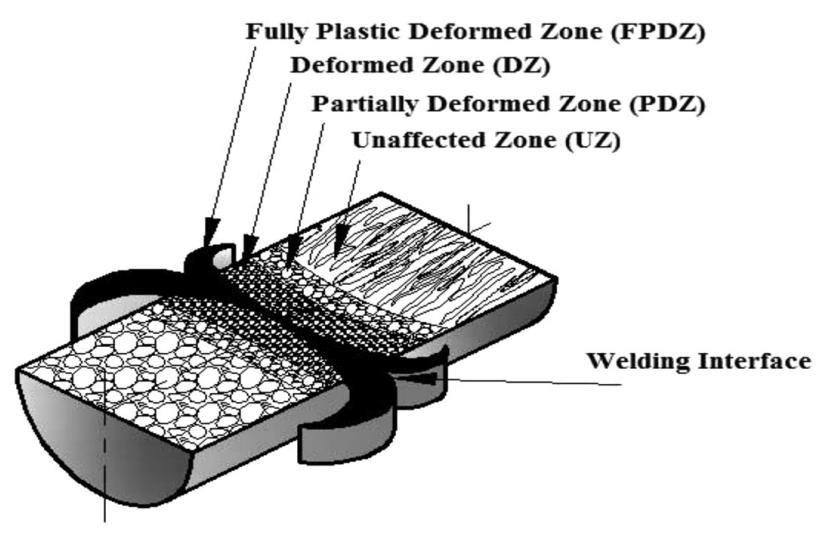

Figure 7: Regions in which occurred microstructural changes 39 Slika 7: Področja, kjer se pojavijo spremembe v mikrostrukturi ${ }^{39}$ interface. From the microstructural observations, the microstructures formed in the interface zone during or after FW processes, there are three distinct zones across the specimens identified as unaffected zone (UZ), deformed zone (DZ) and transformed and recrystallized fully plastic deformed zone (FPDZ). ${ }^{39}$ Typical grain refinement occurred in the DZ region by the combined effect of the thermal and mechanical stresses (Figure 7). A typical micrograph showing the different morphologies of the microstructure at different zones of the friction-processed joint is shown in Figure 7.

According to the International Institute of Welding, welding defects and the explanations of the radiographic images were defined as in Table 6..$^{37,38}$ The films are placed into the viewer shown in Figure 8 and the image is evaluated according to Table 6. It was determined that the most common welding defects shown in Table 6 have a lack of penetration according to the definitions of welding defects and the radiographic images (D) (S2). In other samples the defects were not shown.

In Figure 9 the radiographic testing images of all the samples are shown. The experimental results indicated that AISI 4340 tempered steel could be joined to AISI 2205 duplex stainless steel using the friction-welding technique and for achieving a weld with sufficient strength. The result of the radiographic tests indicated that by increasing the rotation speed, friction pressure and forging pressure the amount of flash increased in all the specimens. In contrast, when increasing the friction time the amount of flash decreased. The best properties of the AISI 4340-2205 steels were observed for the specimens welded at a rotation speed of $2200 \mathrm{~min}^{-1}$, a friction pressure of $40 \mathrm{MPa}$, a forging pressure of 80 


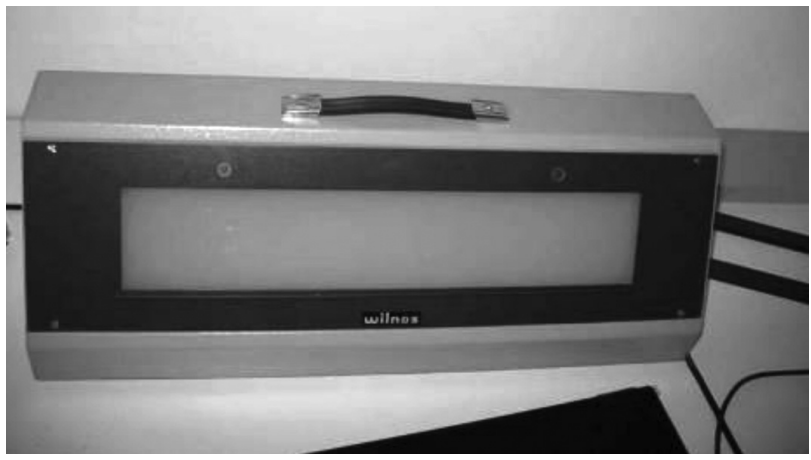

Figure 8: Film-examination device (Viewer) Slika 8: Naprava za pregled filma

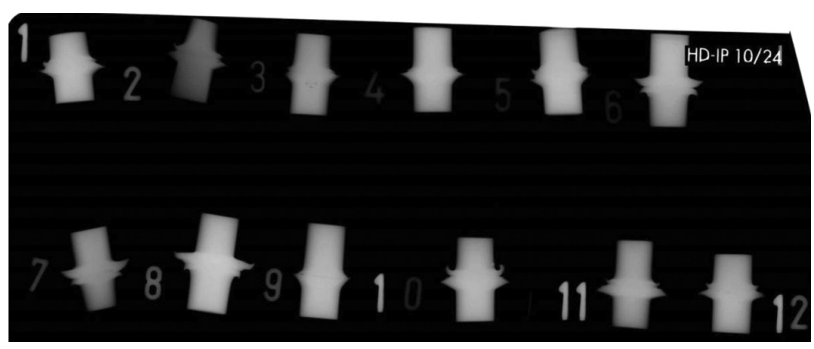

Figure 9: Radiographic test photographs of samples (S1 - S12)

Slika 9: Rentgenski posnetki vzorcev (S1 - S12)

$\mathrm{MPa}$, a friction time of $6 \mathrm{~s}$ and a forging time of $3 \mathrm{~s}$ (Figure 9).

\section{CONCLUSIONS}

In this study, X-ray radiographic testing of AISI 4340 tempered steel and AISI 2205 duplex stainless steel welded with friction welding were investigated. The following results were obtained.

- Friction-welding experiments were carried out using a direct-drive-type friction-welding machine according to Table 5. This study concluded that the AISI 4340 tempered steel could be joined succesfully to AISI 2205 duplex stainless steel using the frictionwelding technique. The best joining was seen in number S7. It was clear that the joining decreased in the other samples.

- Comprehensive microstructural investigations for the AISI 4340-2205 steels' friction-welded joints revealed that there were different regions at the welding interface, the wideness of fully plasticized deformed zone (FPDZ) decreases when rotational speed and friction pressure increase.

- The larger microstructural changes take place in the HAZs. An increase in the contraction of the samples was observed after increasing the friction-welding rotation speeds. The width of the HAZ is mainly affected by the friction time and rotation speed. This infers that the width and formation of HAZs that occurred as a result of the reactions taking place at the welding interface have an adverse effect on the mechanical strength and, consequently, the quality of the friction-welded joints.

- It has been determined that the most common welding defects shown in Table 6 have a lack of penetration according to the definitions of welding defects and the radiographic images (D) (Sample No: 2). In other samples there were no defects. The result of the radiographic tests indicated that by increasing the rotation speed, the friction pressure and the forging pressure the amount of flash increased in all the specimens. In contrast, when increasing the friction time the amount of flash decreased. The best properties of were AISI 4340-2205 steels observed for the specimens welded at a rotation speed of $2200 \mathrm{~min}^{-1}$, a friction pressure of $40 \mathrm{MPa}$, a forging pressure of 80 $\mathrm{MPa}$, a friction time of $6 \mathrm{~s}$ and a forging time of $3 \mathrm{~s}$ (Figure 9).

- The highest deformation was always for the AISI 4340 tempered steel side and in all samples the original structure was preserved in the undeformed region.

\section{REFERENCES}

${ }^{1}$ ASM Handbook on welding, vol. 6, ASM International Publisher, 1993, 471-481

${ }^{2}$ J. Charles, Duplex stainless steel, A Review, Proc. $7^{\text {th }}$ Duplex Int. Conf. \& Expo, Grado, Italy, 2007

${ }^{3}$ J. C. Lippold, D. J. Kotecki, Welding metallurgy and weldability of stainless steels, Wiley-Interscience, 2005

${ }^{4}$ A. V. Jebaraj, L. Ajaykumar, Microstructure analysis and the influence of shot peening on stress corrosion cracking resistance of duplex stainless steel welded joints, Indian Journal of Engineering \& Materials Sciences, 21 (2014), 155-167

${ }^{5}$ S. D. Meshram, T. Mohandas, R. G. Madhusudhan, Friction welding of dissimilar pure metals, Journal of Materials Processing Technology, 184 (2008), 330-337, doi:10.1016/j.jmatprotec.2006.11.123

${ }^{6}$ P. Sathiya, S. Aravindan, A. Noorul Haq, Some experimental investigations on friction welded stainless steel joints, Materials and Design, 29 (2008), 1099-1109, doi:10.1016/j.matdes.2007.06.006

${ }^{7}$ S. Celik, I. Ersozlu, Investigation of the mechanical properties and microstructure of friction welded joints between AISI 4140 and AISI 1050 steels, Mater. Design, 30 (2009), 970-976, doi:10.1016/j.matdes.2008.06.070

${ }^{8}$ http://www.celmercelik.com.

${ }^{9}$ M. Sahin, H. E. Akata, An experimental study on friction welding of medium carbon and austenitic stainless steel components, Indust. Lubricat. Tribol., 56 (2004) 2, 122-129, doi:10.1108/ 00368790410524074

${ }^{10} \mathrm{M}$. Sahin, Evaluation of the joint interface properties of austenitic-stainless steels (AISI 304) joined by friction welding, Materials and Design, 28 (2007), 2244-2250, doi:10.1016/j.matdes.2006.05. 031

${ }^{11}$ I. Kirik, N. Ozdemir, Weldability and joining characteristics of AISI 420/AISI 1020 steels using friction welding, International Journal of Materials Research, 104 (2013) 8, 769-775, doi:10.3139/146.110917

${ }^{12}$ N. Ozdemir, F. Sarsilmaz, A. Hascalik, Effect of rotational speed on the interface properties of friction-welded AISI 304L to 4340 steel, Mater. Des., 28 (2007), 301-307, doi:10.1016/j.matdes.2005.06.011

${ }^{13}$ Welding handbook, Welding Processes, Volume 2, Eighth edition, American Welding Society Inc., Miami 1997, 739-761

${ }^{14}$ R. E. Chalmers, The Friction Welding Advantage, Manufacturing Engineering, 126 (2001), 64-65 


\section{U. CALIGULU et al.: X-RAY RADIOGRAPHY OF AISI 4340-2205 STEELS WELDED BY FRICTION WELDING}

${ }^{15} \mathrm{~N}$. Ozdemir, Investigation of the mechanical properties of frictionwelded joints between AISI 304L and AISI 4340 steel as a function rotational speed, Materials Letters, 55 (2005), 2504-2509, doi:10.1016/j.matlet.2005.03.034

${ }^{16}$ D. E. Spindler, What Industry Needs to Know about Friction Welding, Welding Journal, (1994), 37-42

${ }^{17}$ I. Kirik, N. Ozdemir, U. Caligulu, Effect of particle size and volume fraction of the reinforcement on the microstructure and mechanical properties of friction welded MMC to AA 6061 aluminum alloy, Kovove Mater., 51 (2013) 4, 221-227, doi:10.4149/km_2013_4_221

${ }^{18}$ I. Kirik, N. Ozdemir, F. Sarsilmaz, Microstructure and Mechanical Behaviour of Friction Welded AISI 2205/AISI 1040 Steel Joints, Materials Testing, 54 (2012) 10, 683-687, doi:10.3139/120.110379

${ }^{19}$ M. B. Uday, M. N. Ahmad Fauzi, H. Zuhailawati, A. B. Ismail, Advances in friction welding process: a review, Science and Technology of Welding and Joining, 15 (2010) 7, 534-558, doi:10.1179/136217110X12785889550064

${ }^{20}$ M. Taskin, U. Caligulu, M. Türkmen, X-Ray Tests of AISI 430 and 304 Stainless Steels and AISI 1010 Low Carbon Steel Welded by $\mathrm{CO}_{2}$ Laser Beam Welding, Materials Testing, 53 (2011) 11-12, 741-747, doi:10.3139/120.110283

${ }^{21}$ H. Dikbas, U. Caligulu, M. Taskin, M. Türkmen, X-Ray Radiography of Ti6Al4V Welded by Plasma Tungsten Arc (PTA) Welding, Materials Testing, 55 (2013) 3, 197-202, doi:10.3139/120.110426

${ }^{22}$ http://makina.ktu.edu.tr/static/lab_foy/lab21.doc

${ }^{23} \mathrm{http}: / / \mathrm{www} . w t n d t . m e t u . e d u . t r / n d t / \mathrm{tr} /$ node/ 8

${ }^{24} \mathrm{http}: / /$ asalmakina.com/anasayfam. asp? $\mathrm{sid}=6 \&$ pid $=4$

${ }^{25}$ R. R. da Silva, L. P. Calôba, M. H. S. Siqueira, J. M. A. Rebello, Pattern recognition of weld defects detected by radiographic test NDT\&E International, 37 (2004) 6, 461-470, doi:10.1016/j.ndteint. 2003.12.004
${ }^{26}$ T. Tekiz, The Non-destructive Testings, ITU Faculty of Mechanical Engineering, Istanbul, 1984

${ }^{27}$ M. Albayrak, The Control and Inspection of the Welding Seams, IGDAS, 1997

${ }^{28}$ http://www.ndt-ed.org

${ }^{29} \mathrm{http}: / / \mathrm{www} . \mathrm{wtndt} . \mathrm{metu} . \mathrm{edu} . \mathrm{tr}$

${ }^{30}$ TS EN 444, TS EN 462 Standards, 1994

${ }^{31}$ K. Aoki, Y. Suga, Intelligent image processing for abstraction and discrimination of defect image in radiographic film, Proceedings of the Seventh International Offshore and Polar Engineering Conference, Honolulu, USA, 1997, 527

${ }^{32}$ A. Kehoe, G. A. Parker, Image processing for industrial radiographic inspection: image enhancement, Br J NDT, 32 (1990) 4, 183-190

${ }^{33}$ Y. Cherfa, Y. Kabir, R. Drai, X-rays image segmentation for NDT of welding defects, 7th European Conference on Non Destructive Testing, Copenhagen, 1998, 2782

${ }^{34}$ C. R. Clayton, K. G. Martin, Conf. Proceedings High Nitrogen Steels, The Institute of Metals, Lille, 1989, 256

${ }^{35}$ S. Ekinci, The Evaluation of the Welding Seam Errors with Digital Radiographic Methods, The Atom Energy Foundation of Turkey, Istanbul

${ }^{36}$ The Certificate of Material Testing Knowledge, Eregli Iron and Steel Plants T.A.S

${ }^{37}$ N. Ozakin, H. Baycik, The Radiographic Inspection of the Welding Seam of the Body of Ship, The $4^{\text {th }}$ Iron-Steel Congress, Karabuk, 2007, 289

${ }^{38}$ A. Topuz, The Non-destructive Inspections, YTU, Istanbul, 1993

${ }^{39}$ S. Mercan, N. Ozdemir, A Couple of AISI 2205/AISI 1020 Material Combination with Friction Welding Method, NWSA-Technological Applied Sciences, 2A0080, 8 (2013) 2, 18-34, doi:10.12739/ NWSA.2013.8.2.2A0080 